\title{
An analysis of ecophysiological responses to drought in American Chestnut
}

\author{
William L. BAUERLE ${ }^{\text {a* }}$, G. Geoff WANG ${ }^{\mathrm{b}}$, Joseph D. BoWDEN ${ }^{\mathrm{a}}$, Christina M. HoNG ${ }^{\mathrm{c}}$ \\ ${ }^{\text {a }}$ Department of Horticulture, Clemson University, Clemson, SC 29634-0319, USA \\ ${ }^{b}$ Department of Forestry and Natural Resources, Clemson University, Clemson, SC 29634, USA \\ ${ }^{\mathrm{c}}$ Governors School of Math and Science, Hartsville, SC 29550, USA
}

(Received 24 January 2006; accepted 27 March 2006)

\begin{abstract}
With the anticipated reintroduction of blight resistant American chestnut (Castanea dentata [Marsh.] Borkh.), it is important to understand physiological responses of the species to various environmental stresses. To test the hypothesis that instantaneous water use efficiency (WUE $\mathrm{E}_{\mathrm{i}}$ ) of American chestnut seedlings is increased by water stress, we measured gas exchange, leaf optical properties, and growth of American chestnut seedlings under well-watered and drought in both glasshouse and field conditions. Under well-watered conditions, field grown seedlings had consistently higher net photosynthesis $\left(A_{\text {net }}\right)$ and leaf stomatal conductance $\left(g_{\mathrm{s}}\right)$ values than glasshouse seedlings. Under drought conditions, both field and glasshouse grown seedlings responded with a general increase in $\mathrm{WUE}_{\mathrm{i}}$. Compared to well-watered conditions, drought stress significantly reduced the amount of light absorption regardless of growth environment. Under well-watered conditions, both field and glasshouse grown seedlings had similar maximum net photosynthesis rate $\left(A_{\max }\right)$ and maximum rate of ribulose 1,5 bisphosphate regeneration $\left(J_{\max }\right)$; however, maximum carboxylation $\left(\mathrm{Vc}_{\max }\right), \mathrm{CO}_{2}$ compensation point $(\Gamma)$, carboxylation efficiency $(\mathrm{CE})$, and dark respiration $(R)$ were substantially higher in the field grown seedlings. When WUE $\mathrm{i}_{\mathrm{i}}$ values are compared to those of prevailing deciduous hardwood species that now inhabit American chestnuts once native range, we conclude that American chestnut has an advantageous preadaptation to water stress that might be a key survival determinant when it is reintroduced.
\end{abstract}

leaf conductance / net photosynthesis / water-use efficiency

Résumé - Analyse des réponses écophysiologiques à la sécheresse du châtaignier américain. Pour anticiper la réintroduction du châtaignier américain (Castanea dentata [Marsh.] Borkh.) résistant à la rouille, il est important de comprendre les réponses physiologiques de cette espèce aux différents stress environnementaux. Pour tester l'hypothèse que l'efficience instantanée de l'eau (WUE $\mathrm{i}_{\mathrm{i}}$ ) des semis de châtaignier américain est augmentée par le stress hydrique, nous avons mesuré les échanges gazeux, les propriétés optiques des feuilles et la croissance de semis bien alimentés en eau et de semis soumis à une sécheresse élevés en serre et en conditions extérieures. Dans le cas d'une bonne alimentation en eau, les semis poussant à l'extérieur ont eu constamment des valeurs plus élevées de photosynthèse nette $\left(A_{\text {net }}\right)$ et de conductance foliaire $\left(g_{\mathrm{s}}\right)$ que celles des semis élevés en serre. Dans le cas de semis soumis à la sécheresse, les semis élevés en serre et ceux élevés en extérieur répondent par un accroissement général de WUE $\mathrm{E}_{\mathrm{i}}$. Comparativement aux conditions de bonne alimentation hydrique, la sécheresse réduit significativement la quantité de lumière absorbée indépendamment des conditions environnementales. En condition de bonne alimentation hydrique, les semis élevés en serre et en extérieur ont un taux maximum de photosynthèse nette $\left(A_{\max }\right)$ et un taux maximum de régénération du ribulose 1,5 biphosphate $\left(J_{\max }\right)$ similaires; toutefois, le maximum de carboxylation $\left(\mathrm{Vc}_{\max }\right)$, le point de compensation du $\mathrm{CO}_{2}(\Gamma)$, l'efficience de carboxylation $(\mathrm{CE})$, et la respiration obscure $(R)$ étaient beaucoup plus élevés chez les semis poussant en extérieur. Lorsque les valeurs de $\mathrm{WUE}_{\mathrm{i}}$ sont comparées avec celles de feuillus caducifoliés courants qui habitent maintenant la région naturelle du châtaignier américain, nous concluons que le châtaignier américain a une avantageuse préadaptation au stress hydrique qui pourrait être une clé déterminante pour sa survie quand il sera réintroduit.

conductance foliaire / photosynthèse nette / efficience d'utilisation de l'eau

\section{INTRODUCTION}

Before the introduction of chestnut blight, American chestnut (Castanea dentata [Marsh.] Borkh.) comprised 40-45\% of the canopy $[22,34]$ and $50 \%$ of timber by volume on noncalcareous well-drained slopes in the southern Appalachian Mountain range of the eastern United States [8, 9, 41]. By the early to mid 20th century, the introduction of Cryphonectria parasitica (Murr.) Barr, the phloem pathogen responsible for predisposing American chestnut to an aggressive canker disease, eradicated American chestnut from the forest overstory.

\footnotetext{
*Corresponding author: bauerle@clemson.edu
}

A backcrossing breeding program overseen by the American Chestnut Foundation that combines blight-resistant traits of Castanea mollissima (Chinese chestnut) is well underway with plans to reintroduce resistant varieties. Blight-resistant hybrids with approximately $6 \%$ Chinese chestnut genetic inheritance are scheduled to be available for planting within 3-4 years (P. Sisco, American Chestnut Foundation, Pers. Comm.). Except for resistance to chestnut blight, the breeding program does not intend for the hybrids to differ from that of pure American chestnut. Therefore, it is important to document the ecophysiological response of pure American chestnut to the effects of drought for comparison to introduced blight 
resistant hybrids and existing hardwood species. Given the economic importance of the species prior to the blight, the undocumented ecophysiological responses of pure American chestnut to water stress, and the approaching reintroduction of resistant hybrids, the timing is right to assess the ability of the species to survive drought.

Presently, little is known about American chestnut populations on xeric forest sites, where chestnuts were often found in pure stands prior to the blight [8]. A review of the literature reveals a paucity of data regarding American chestnut drought tolerance and performance under soil water deficits. In fact, with respect to blight tolerance, Griffin et al. [15] observed more blight on mesic as opposed to xeric sites, prompting the investigation of the role of xeric conditions in natural hypovirulence biocontrol of the blight fungus [16]. Interestingly, post blight populations of American chestnut exist mostly in the understory of xeric slope hardwood forests [16]. Thus, a more in depth understanding of American chestnut response to drought stress is warranted.

Water deficits influence a wide array of physiological processes, including photosynthetic carbon assimilation, stomatal conductance, and light absorption [19]. Changes in climate have raised concerns about potential impacts of precipitation on forest response to decreased soil water availability [14]. Predictions made by global climate models, moreover, indicate that precipitation will continue to fluctuate [38], which could produce conditions where evapotranspiration exceeds summer precipitation recharge. As a result, an increase in water stress conditions will likely predominate future reforestation and afforestation efforts both within and beyond the native range of American chestnut [19].

In this study, our objectives were to document physiological values for pure American chestnut, and more importantly, investigate the ecophysiological response of American chestnut to substrate and soil moisture deficit. Comparative measurements from two different environments were made to assess the degree of variation in the gas exchange properties and to broaden the applicability of the detailed glasshouse study to field situations. The glasshouse grown plants were subjected to unnatural atmospheric conditions in conjunction with a soilless substrate, whereas the field grown plants were grown under natural atmospheric and soil conditions. The drought treatment was a mechanism to potentially magnify physiological responses, while deciphering drought tolerance. We hypothesized that water use efficiency of American chestnut seedlings is increased by water stress, which should be maintained and also selected for during the development of blight resistant hybrids.

\section{MATERIALS AND METHODS}

\subsection{Experiment 1 (glasshouse study): Plant material and experimental conditions}

Seeds for the glasshouse study were collected near Reedsburg,

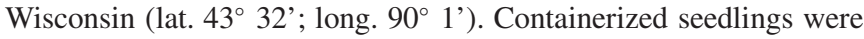
established by direct seeding into $3.7 \mathrm{~L}$ plastic pots containing a standard glasshouse potting substrate mixture of peat moss, pine bark and

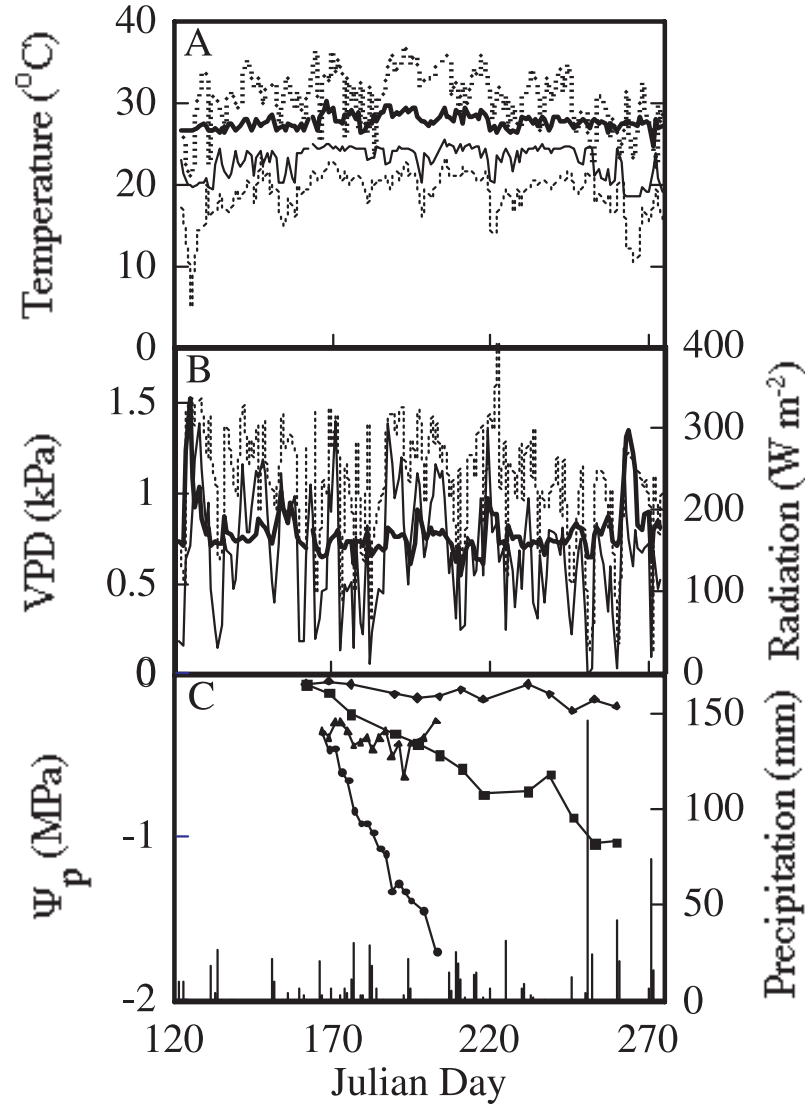

Figure 1. Temperature (A), vapor pressure deficit (VPD) (B), radiation $(\mathbf{B})$, predawn water potential $\left(\Psi_{\mathrm{p}}\right)(\mathbf{C})$, and precipitation (C) throughout the study period. Four lines are shown in A; the black solid thin line illustrates minimum daily glasshouse temperature whereas the solid thick black line illustrates maximum daily glasshouse air temperature. Field minimum and maximum air temperatures are illustrated in the same fashion with broken lines. Three lines are shown in $\mathbf{B}$; the solid black thick line illustrates average daily glasshouse VPD whereas the solid thin black line illustrates average daily field VPD. The broken line illustrates radiation. Four horizontal and one vertical line are shown in $\mathbf{C}$; $(\diamond)$ symbols indicate mean control field $\Psi_{\mathrm{p}}$ values and (ם) denote the drought treatment. Triangles $(\Delta)$ illustrate the mean control glasshouse $\Psi_{\mathrm{p}}$ values and $(\bullet)$ represent the glasshouse drought stress treatment. Precipitation at the field site is illustrated with solid vertical lines.

perlite/vermiculite (2:1:1, v/v) (Fafard 3B, Fafard Inc., Anderson, SC, USA). Prior to experiment initiation, they were grown in a glasshouse under full sun and well-watered conditions at the Clemson University Biosystems Research Complex (Clemson, SC, USA) (Fig. 1). The glasshouse experiment consisted of a total of 20 randomly selected plants, chosen for repeated sampling of gas exchange, light absorption, height, leaf number, stem caliper, and canopy width. Of the 20 plants, 10 plants were randomly assigned to a drought treatment and 10 plants were randomly assigned to a well-watered control.

\subsubsection{Substrate water and measurements}

At thirty days from sowing, pots were watered to container capacity and allowed to drain for $24 \mathrm{~h}$. After drainage and thereafter, 


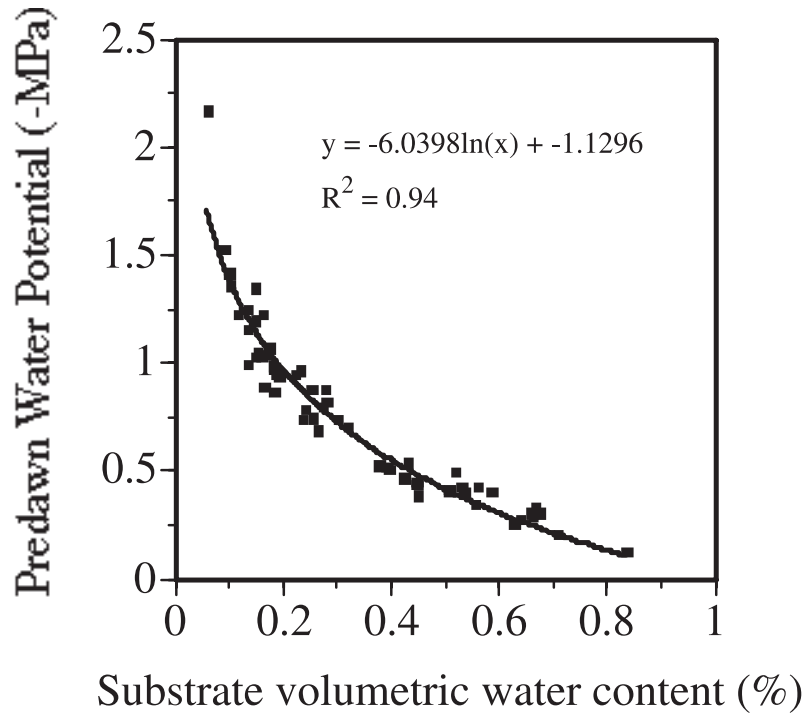

Figure 2. Relationship between volumetric water content (\%) and predawn soil water potential determined for the substrate used in the experiment.

drought treatment plants were not irrigated whatsoever and controls were kept well-watered. On alternate days, bulk volumetric water content of each container was measured in two locations with a theta $(\theta)$ Probe type ML2 (Delta-T Devices, Cambridge, England). The readings were taken in opposite sides of the pot. Probe prongs were long enough to allow the probe contact with the top two thirds of substrate depth. The readings were averaged in order to estimate bulk volumetric water content for each container, where predawn water potential $\left(\Psi_{\mathrm{p}}\right)$ was used as a surrogate for soil water potential. For paired water potential versus $\theta$ readings, one leaf per tree was selected on 20 seedlings that were grown on an adjacent glasshouse bench. Leaves were removed and their water potential measured at predawn using a Scholander-Hammel pressure chamber (Soil Moisture, Santa Barbara, California, USA) during the course of a dry down. To convert $\theta$ to $\Psi_{\mathrm{p}}$, the non-linear relationship illustrated in Figure 2 was used to develop the conversion equation (Fig. 2). Due to the destructive nature of leaf water potential measurements, this independent technique prevents destructive leaf harvesting on the main study plants and a rapid means to assess plant water status $[4,13,35]$.

\subsubsection{Leaf gas exchange}

Prior to arrival at a moisture status of $0.10 \mathrm{~m}^{3} \mathrm{~m}^{-3}$ (a value determined to equal $-1.5 \mathrm{MPa}$ in a preliminary experiment; Fig. 2), plants were measured every $2 \mathrm{~d}$, and beyond that moisture level, plants were measured every $4 \mathrm{~d}$ until visual leaf wilt occurred at solar noon (36 continuous days of non-irrigated conditions). Net photosynthesis $\left(A_{\text {net }}\right)$, leaf stomatal conductance $\left(g_{\mathrm{s}}\right)$, and dark respiration $(R)$ rate at $370 \mu \mathrm{mol} \mathrm{mol}{ }^{-1} \mathrm{CO}_{2}$ were measured on the first fully expanded leaf using a portable steady state gas-exchange system (CIRAS-I, PP Systems, Amesbury, Mass., USA) equipped with a light and temperature controlled cuvette (model PLC5 (B); PP Systems). From the terminal tip, measurements were taken on the youngest fully expanded leaf from 0900 to 1230 HR. On any given day, plant measurements were taken in random order to compensate for any effects caused by time of sampling. Leaf temperature within the cuvette was controlled at $25^{\circ} \mathrm{C}$ and photosynthetic photon flux density (PPFD) was maintained at $1200 \mu \mathrm{mol} \mathrm{m} \mathrm{m}^{-2} \mathrm{~s}^{-1}$ with the cuvette light source. Vapor pressure deficit (VPD) in the cuvette was kept at $1.2 \pm 0.2 \mathrm{kPa}-$ a predetermined value that did not cause $g_{\mathrm{s}}$ decline. The temperature set point was taken as optimum for temperate-zone $\mathrm{C}_{3}$ species [24]. Measurements were recorded after reaching steady state.

The relationship between photosynthesis and internal $\mathrm{CO}_{2}$ concentration $\left(A-C_{\mathrm{i}}\right.$ curves, where $A$ is net photosynthetic rate in $\mu \mathrm{mol} \mathrm{m} \mathrm{m}^{-2} \mathrm{~s}^{-1}$ and $C_{\mathrm{i}}$ is internal $\mathrm{CO}_{2}$ concentration expressed as the mol fraction of $\mathrm{CO}_{2}$ ) was only determined on replicates of wellwatered seedlings to prevent artifacts of stomatal patchiness under drought stress conditions. Other than $\mathrm{CO}_{2}$ manipulation, the cuvette conditions for $A-C_{\mathrm{i}}$ curves were the same as above. Measurements began at a cuvette $\mathrm{CO}_{2}$ concentration of $370 \mu \mathrm{mol} \mathrm{mol}^{-1}$ and were completed in the following sequence: $370,1200,1000$ and 800,600, $370,175,150,100,50 \mu \mathrm{mol} \mathrm{mol}{ }^{-1}$ to generate the $A-C_{\mathrm{i}}$ curves. Throughout this experiment, model parameters from the biochemical photosynthetic $\mathrm{CO}_{2}$ response model of Farquhar and von Caemmerer [11] and Kirschbaum and Farquhar [23] were used. The model estimated the maximum rate of carboxylation $\left(\mathrm{Vc}_{\max }\right)$, the maximum rate of ribulose 1,5-bisphosphate regeneration (assumed to equal the maximum rate of coupled photosynthetic electron transport) $\left(J_{\max }\right)$, and the $\mathrm{CO}_{2}$ compensation point by the biochemical model of Farquhar et al. [12], following the subsequent modifications of Sharkey [36], Harley and Sharkey [17], and Harley et al. [18]. Carboxylation efficiency (CE) was estimated by least-squares regression [30]. Nonlinear regression techniques for estimating $\mathrm{Vc}_{\max }, J_{\max }$, and triose phosphate utilization (TPU) followed Wullschleger [40]. For each plant, the non-linear regression curve explained $>92 \%$ of the variation in $A-C_{\mathrm{i}}$ data.

Light response curves were measured on the same leaves used to construct $A-C_{\mathrm{i}}$ curves. The ambient $\mathrm{CO}_{2}$ concentration, leaf temperature, and VPD were set identical to the $A-C_{\mathrm{i}}$ experiment. Prior to measurement, plant leaves were illuminated at approximately 750 $900 \mu \mathrm{mol} \mathrm{m} \mathrm{m}^{-2} \mathrm{~s}^{-1}$ for $20 \mathrm{~min}$ in a growth chamber and then measured in random order. Photosynthetic photon flux density was monitored with a quantum sensor (LiCor -189, LiCor, Inc., Lincoln, Nebraska, USA). The following sequence of PPFD was implemented: 1200 , $900,600,425,300,200,100,50$, and $0 \mu \mathrm{mol} \mathrm{m}^{-2} \mathrm{~s}^{-1}$ with the cuvette light source. Carbon uptake was then measured and data recorded after exchange rates stabilized. Light response curve analysis followed methodology described in Parsons et al. [33]:

$$
A_{\text {net }}=\frac{\alpha Q+A_{\max }-\sqrt{\left(\alpha Q+A_{\max }\right)^{2}-4 \alpha Q k A_{\max }}}{2 k}-R_{\text {day }}
$$

where leaf net photosynthesis $\left(A_{\text {net }}\right)$ was modeled as a non rectangular-hyperbola in response to light level $(Q)$ and maximum light saturated photosynthesis $\left(A_{\max }\right)$ is the upper asymptote. Quantum efficiency ( $\alpha$, corrected for light absorption following Bauerle et al. [6]), and light compensation point $\left(I_{c}\right)$ were calculated from the linear portion of the initial part of the light response curve and axis intercepts. Model parameters of convexity $(k)$ and light saturation $\left(I_{\mathrm{sat}}\right)$ were obtained from least squares curve fitting and $R_{\text {day }}$ accounts for the release of $\mathrm{CO}_{2}$ in the light by processes other than photorespiration. The non-linear regression coefficients of determination explained $>95 \%$ of the variation in the $A_{\text {net }}$ versus PPFD curves. 


\subsubsection{Water use efficiency calculation}

We calculated the instantaneous water use efficiency $\left(\mathrm{WUE}_{\mathrm{i}}\right)$ on a mass basis from $A_{\text {net }}$ and transpiration:

$$
\mathrm{WUE}=\frac{\left(\mathrm{gmol}^{-1} \mathrm{CO}_{2}\right)}{\left(\mathrm{gmol}^{-1} \mathrm{H}_{2} \mathrm{O}\right)}
$$

where the molar masses of $\mathrm{CO}_{2}\left(44.0 \mathrm{~g} \mathrm{~mol}^{-1}\right)$ and $\mathrm{H}_{2} \mathrm{O}\left(18 \mathrm{~g} \mathrm{~mol}^{-1}\right)$ are used to calculate $\mathrm{WUE}_{\mathrm{i}}\left(\mathrm{g} \mathrm{CO}_{2}\left(\mathrm{~kg} \mathrm{H}_{2} \mathrm{O}\right)^{-1}\right)$.

\subsubsection{Leaf optical property quantum yield determination}

Leaf absorption, reflectance, and transmittance were estimated with a Minolta SPAD 502 chlorophyll meter (Minolta Camera Co., Ramsey, New Jersey). The SPAD reading (a unitless value), is nonlinearly correlated with leaf absorption, reflectance, and transmittance [6]. The SPAD value is related to chlorophyll content and leaf greenness, where a silicon photodiode measures the ratio of transmittance through the leaf tissue for spectral bands at 650 and $940 \mathrm{~nm}$ wavelengths. Five SPAD readings were measured and averaged for each of 10 replicate leaves per treatment every $4 \mathrm{~d}$ during the study. SPAD readings from sampled leaves were converted to leaf absorption, reflectance, and transmittance by inserting SPAD values into equations developed from non-linear exponential models [6]. The percent photosynthetic active radiation absorption of each leaf was used to correct for light lost when calculating quantum yield.

\subsubsection{Seedling growth}

During the duration of the glasshouse study, temperature and VPD were within the optimum range for $\mathrm{C}_{3}$ species [24] (Fig. 1). Seedlings were grown in ambient sunlight (Fig. 1). Nondestructive growth measurements were taken every $4 \mathrm{~d}$, where height (HT) and root collar diameter (RCD) were measured on all 10 replicates per treatment, and a cylindrical volume index was calculated as an estimate of absolute growth rate expressed as cylindrical volume index (the diameter squared multiplied by height). Height was measured to the nearest $0.1 \mathrm{~cm}$ using a measuring tape, and RCD was measured to the nearest $0.01 \mathrm{~mm}$ using a digital caliper. At the end of the experimental period (late July, 2004), all seedlings were destructively sampled. Each seedling was carefully excavated, roots were washed, and leaf area of all trees was measured with an LI-3100 leaf area meter (Li-Cor, Inc., Lincoln, Nebraska). Root (RW), stem (SW) and leaf (LW) biomass were determined by drying to a constant mass at $70{ }^{\circ} \mathrm{C}$.

\subsubsection{Data Analysis}

Gas exchange data were normalized by log transformation. Treatment effects on growth, gas exchange, and leaf optical properties were evaluated by analysis of variance (ANOVA) with a repeated measures univariate general linear model (SPSS Institute Inc., 2000).

\subsection{Experiment 2 (field study): Plant material and experimental conditions}

Seeds for the field study were collected near Lansing, Michigan at a location that is of similar latitude (lat. $43^{\circ} 31^{\prime}$; long. $83^{\circ} 46^{\prime}$ ) and within the same geographic population as the seeds in the glasshouse container study [20]. Seeds for the plantation study were grown under nursery conditions for 2 years in Trenton, SC, shipped to Clemson, $\mathrm{SC}$, and transplanted at $2 \times 2 \mathrm{~m}$ spacing at the Clemson Forest Operations Laboratory in the spring of 2002. To simulate a natural planting but protect seedlings from browsing, they were planted within a fence and no fertilizer or herbicide was applied to the plot. In the field population, 16 randomly selected trees were chosen for repeated sampling of gas exchange, light absorption, height, leaf number, stem caliper, and canopy width measurements. Eight were randomly assigned to the drought treatment and 8 to the well-watered control.

\subsubsection{Soil water treatment}

On June 10th of 2004, plastic sheeting was laid out on the soil surface for each of 8 replicate drought treatment trees to cover an area four times greater than the seedling canopy drip line. The plastic sheeting was furrowed into the top $10 \mathrm{~cm}$ of soil and laid out in the case of a precipitation event. The sheeting prevented soil water recharge, and thereby allowed transpiration to naturally deplete soil water until September 17th, 2004 (Fig. 1). Rolling the plastic sheeting up after a precipitation event allowed gas flux from the soil, precluded soil temperature alteration, and prevented precipitation accumulation in individual plastic moisture barriers.

\subsubsection{Leaf gas exchange}

Unless otherwise noted, $A_{\text {net }}, g_{\mathrm{s}}$, and $R$ were measured in the same way as in the glasshouse study. Plants were measured once a week for 13 continuous weeks and measurements always began the morning after predawn water potential readings (see specific dates below).

\subsubsection{Leaf optical property determination}

Leaf absorption characteristics were estimated using methodology described in Experiment 1.

\subsubsection{Predawn xylem pressure potential}

Predawn xylem pressure potential was measured with a Scholander-Hammel pressure chamber on two leaves that were taken at mid-canopy position from each of the 8 treatment and 8 control trees and averaged per treatment. On 13 days (June 10, 17, 24; July 8, 15, 22, 29; Aug. 5, 19, 26; and Sept. 2, 9, and 16) during the summer of 2004, predawn water potential was measured. Water potential reading protocols followed Bauerle et al. [3] where a sharp razor blade was used to remove the leaf and the time between excision and pressurization did not exceed $20 \mathrm{~s}$. Natural field conditions are illustrated in Figure 1, where precipitation recharge exceeded levels that would preclude drought (http://www.drought.unl.edu/).

\subsubsection{Data analysis}

Statistical procedures followed that of the first experiment. 
Table I. $\mathrm{CO}_{2}$ response gas exchange parameters of well-watered American chestnut at $25^{\circ} \mathrm{C}$ and VPD maintained at $1.2 \pm 0.2 \mathrm{kPa}$ maximum net photosynthesis rate at maximum $\left[\mathrm{CO}_{2}\right]$ and saturating light $\left(A_{\max }\right)$ and carboxylation efficiency $(\mathrm{CE})$ were estimated by least-squares regression [25]. Dark respiration $(R)$ was measured after each curve. Maximum carboxylation $\left(\mathrm{Vc}_{\max }\right)$, estimates of the maximum rate of ribulose 1,5 bisphosphate regeneration $\left(J_{\max }\right)$, triose phosphate utilization (TPU), and $\mathrm{CO}_{2}$ compensation point $(\Gamma)$ were calculated from the biochemical model of Farquhar et al. [9], following the subsequent modifications of Sharkey [30], Harley and Sharkey [13], and Harley et al. [14]. Abbreviations after the species represent glasshouse (gl), and field (fd) conditions.

\begin{tabular}{lcc}
\hline Parameter & A. chestnut $(\mathrm{gl}) \pm \mathrm{se}$ & A. chestnut $(\mathrm{fd}) \pm \mathrm{se}$ \\
\hline$A_{\max }\left(\mu \mathrm{mol} \mathrm{m} \mathrm{s}^{-2}\right)$ & $13.40 \pm 0.17^{*}$ & $15.60 \pm 0.30^{*}$ \\
$R($ measured $)\left(\mu \mathrm{mol} \mathrm{m}^{-2} \mathrm{~s}^{-1}\right)$ & $-1.86 \pm 0.08^{* *}$ & $-3.16 \pm 0.15^{* *}$ \\
$\mathrm{Vc}_{\max }\left(\mu \mathrm{mol} \mathrm{m}{ }^{-2} \mathrm{~s}^{-1}\right)$ & $41.51 \pm 0.45^{* *}$ & $48.66 \pm 0.45^{* *}$ \\
$J_{\max }\left(\mu \mathrm{mol} \mathrm{m} \mathrm{s}^{-1}\right)$ & $101.72 \pm 0.62^{*}$ & $106.24 \pm 0.78^{*}$ \\
$\Gamma\left(\mu \mathrm{mol} \mathrm{mol}{ }^{-1}\right)$ & $12.08 \pm 0.17^{* *}$ & $92.22 \pm 0.37^{* *}$ \\
TPU $\left(\mu \mathrm{mol} \mathrm{m}^{-2} \mathrm{~s}^{-1}\right)$ & $6.36 \pm 0.14$ & $5.82 \pm 0.26$ \\
CE $\left(\right.$ initial slope of $\left.A_{\text {net }} \mathrm{vs}_{\mathrm{i}}\right)$ & $0.96 \pm 0.08^{* *}$ & $0.53 \pm 0.11^{* *}$ \\
\hline
\end{tabular}

Significant differences between populations are given as probabilities of a separate variance $t$-test between glasshouse and field: $* p<0.05$; $* * p<0.01$

\section{RESULTS}

\subsection{Gas exchange}

The drought treatment seedling $A_{\text {net }}$ and $g_{\mathrm{s}}$ declined as the season progressed and water stress intensified (Fig. 3). Although the decline in the glasshouse gas exchange occurred over a shorter time frame as opposed to the field site, the glasshouse control had less than half the rate of $A_{\text {net }}$ and $g_{\mathrm{s}}$ as compared to seedlings from the field environment (Fig. 3). Even though $A_{\text {net }}, g_{\mathrm{s}}$, and $\mathrm{WUE}_{\mathrm{i}}$ differed significantly $(P<$ 0.01 ) between glasshouse and field grown seedlings in response to water stress (Fig. 4), both environmental populations increased their $\mathrm{WUE}_{\mathrm{i}}$ as drought progressed. After reaching a $\Psi_{\mathrm{p}}$ of approximately $-1 \mathrm{MPa}$, the highest attainable water-stress at the field, the field environmental population had a $W E_{i}$ similar to the glasshouse population (Figs. 1 and 4, respectively). Beyond approximately $-1.5 \mathrm{MPa} \Psi_{\mathrm{p}}$, the glasshouse environmental population wilted severely at solar noon and leaf $A_{\text {net }}$ and $g_{\mathrm{s}}$ failed to recover (Fig. 4). Under wellwatered conditions, mean $A_{\max }$ and $J_{\max }$ differed significantly $(p<0.05)$ between the glasshouse and field, although the magnitude of these differences were small (Tab. I). Greater differences in $\mathrm{Vc}_{\max }, \Gamma, \mathrm{CE}$, and $R$ values were observed between the glasshouse and field, with significantly $(p<0.01)$ higher values found in the field grown seedlings (Tab. I). There were no significant differences in TPU between glasshouse and field measurements. Table II illustrates the $R_{\mathrm{a}}, \alpha, I_{\mathrm{c}}, \mathrm{k}$, and $I_{\mathrm{sat}}$ of the well-watered seedlings within the glasshouse environmental population for comparative purposes.

\subsection{Leaf optical properties}

Differences in the amount of absorbed light between wellwatered and water-stressed seedlings were significant (Fig. 5). Reduction of light absorption in response to drought stress was greater in the field environmental population $\left(\Psi_{\mathrm{p}}=-1 \mathrm{MPa}\right)$ compared to the glasshouse population $\left(\Psi_{p}=-1.5 \mathrm{MPa}\right)$. Relative leaf greenness readings had slightly lower values in the

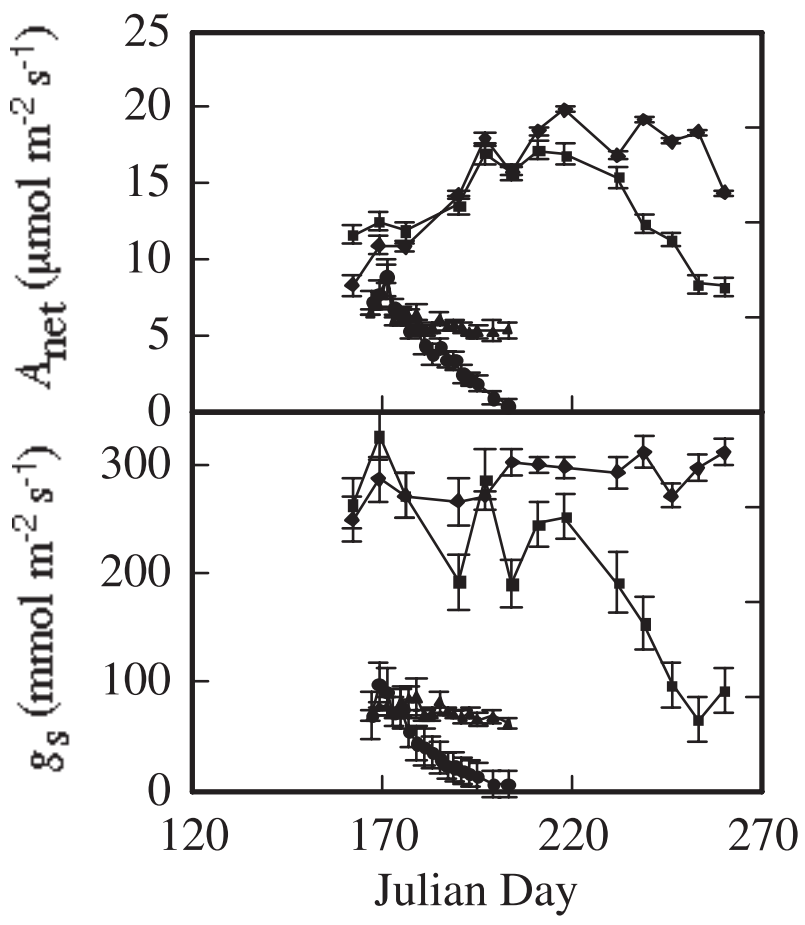

Figure 3. Net photosynthesis $\left(A_{\text {net }}\right)$ and stomatal conductance to water vapor $\left(g_{\mathrm{s}}\right)$ of well watered $(\boldsymbol{\Delta})$ and water-stressed $(\bullet)$ glasshouse American chestnut seedlings and control ( $\downarrow)$ and drought stressed (घ) field planted American chestnut during the study period. Each value represents a mean \pm SE for the glasshouse $(n=10)$ and the field site $(n=8)$.

water stress treatment, indicating lower chlorophyll levels for light absorption.

\subsection{Growth and biomass allocation}

Differences in growth rate between well-watered and water-stressed glasshouse seedlings were not significant until 


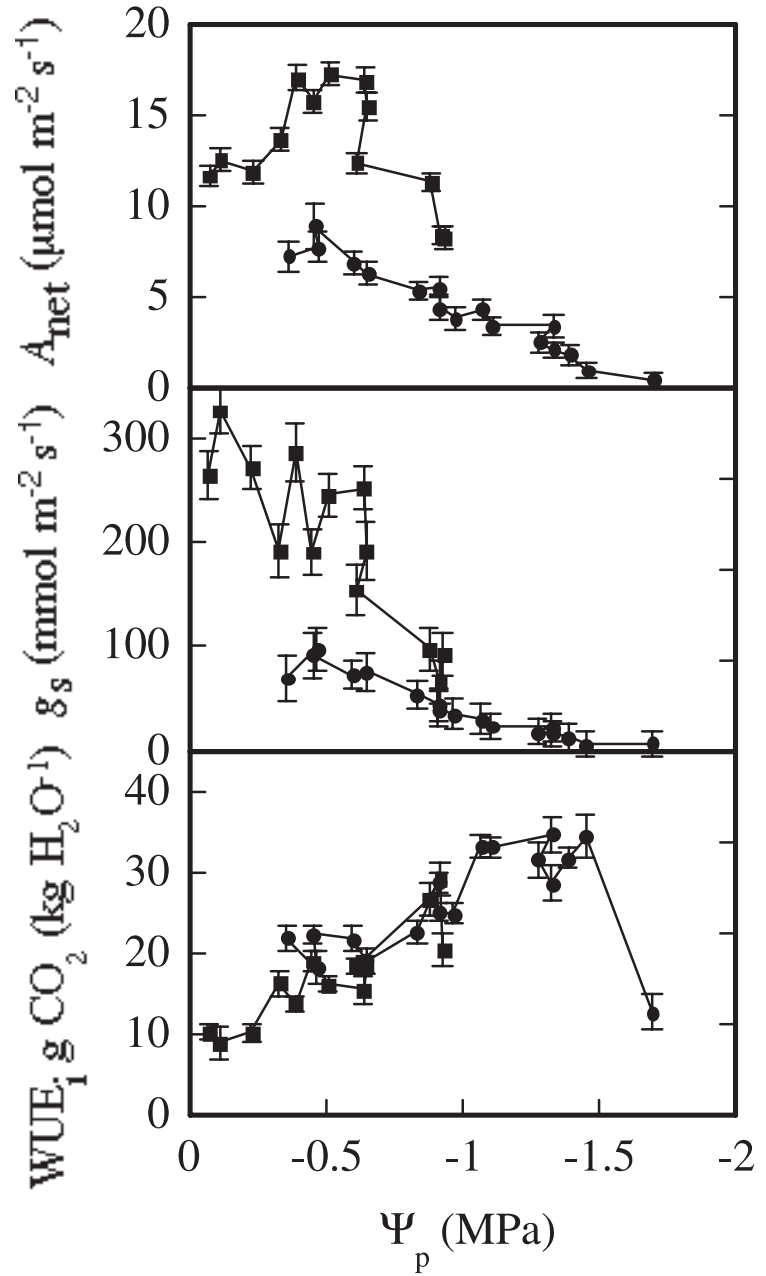

Figure 4. Net photosynthesis $\left(A_{\text {net }}\right)$, stomatal conductance to water vapor $\left(g_{\mathrm{s}}\right)$, instantaneous water use efficiency $\left(\mathrm{WUE}_{\mathrm{i}}\right)$ versus predawn water potential $\left(\Psi_{\mathrm{p}}\right)$ of water-stressed American chestnut seedlings. Each value represents a mean \pm SE for the glasshouse $(n=10)$ and the field site $(n=8)$. The glasshouse population is represented by solid circles $(\bullet)$ and the field population by solid squares (घ).

20 days of continuous water deprivation. After 20 days of withholding water from the drought treatment, growth progressed slowly and leveled off from day 24 through 36 (Fig. 6). Compared to the well-watered treatment, the water-stressed seedlings showed visual signs (less height growth and less caliper) of diminished growth as water-stress intensity increased. However, mortality due to water deficits was not observed.

At the end of the experiment, total biomass and most biomass components differed $(p<0.05)$ among the two water treatments (Tab. III). Total biomass, root biomass, and shoot biomass were lower in the water stressed treatment. Although leaf biomass was lower, it was not significantly different $(p=$ $0.153)$. The root to shoot ratio decreased in the drought treatment, whereas the leaf weight ratio and leaf weight root ratio, specific leaf area, leaf area ratio and leaf area root ratio in-
Table II. Light response gas exchange parameters of well-watered glasshouse grown American chestnut seedlings at $25^{\circ} \mathrm{C}$ and VPD maintained at $1.2 \pm 0.2 \mathrm{kPa}$. We followed methodology described in Parsons et al. [33], where apparent dark respiration $\left(R_{\mathrm{a}}\right)$, quantum yield ( $\alpha$, corrected for light absorption following Bauerle et al. [6], and light compensation point $\left(I_{c}\right)$ were calculated from the linear portion of the initial part of the light response curve and axis intercepts. Model parameters of convexity or the bending rate of the curve $(k)$ and light saturation $\left(I_{\text {sat }}\right)$ were obtained from least squares curve fitting.

\begin{tabular}{lc}
\hline Parameter & Mean $\pm \mathrm{se}$ \\
\hline$R_{\mathrm{a}}\left(\mu \mathrm{mol} \mathrm{m} \mathrm{m}^{-2}\right)$ & $-1.97 \pm 0.19$ \\
$\alpha\left(\mu \mathrm{mol} \mathrm{CO} \mathrm{Cmol}^{-1}\right.$ photon $)$ & $0.056 \pm 0.01$ \\
$I_{\mathrm{c}}\left(\mu \mathrm{mol} \mathrm{m} \mathrm{m}^{-1}\right)$ & $29.48 \pm 0.27$ \\
$k$ & $0.67 \pm 0.06$ \\
$I_{\mathrm{sat}}\left(\mu \mathrm{mol} \mathrm{m} \mathrm{s}^{-1}\right)$ & $203.50 \pm 0.65$ \\
\hline
\end{tabular}

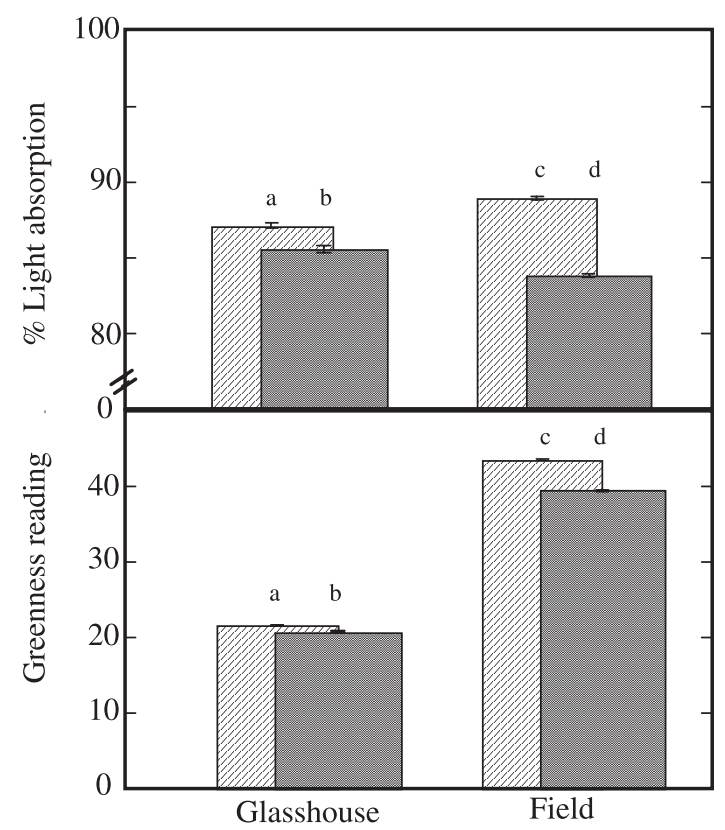

Figure 5. (A) Leaf light absorption (\%) within the photosynthetic 400 to $700 \mathrm{~nm}$ wavelength range for American chestnut. Means $(n=10)$ are hatched for irrigated and solid for drought treatment. The means followed by the same letter are not significantly different $(p<0.05)$. Bars represent SE. (B) Greenness reading where means $(n=10)$ are hatched for irrigated and solid for drought treatment. The means followed by the same letter are not significantly different $(p<0.05)$.

creased (Tab. III). Leaf area and leaf biomass, on the other hand, did not significantly change between treatments.

\section{DISCUSSION}

The water deficits caused stress in seedlings at both sites, even though the field grown seedlings did not exceed approximately $-1 \mathrm{MPa} \Psi_{\mathrm{p}}$. Calculated $\Psi_{\mathrm{p}}$ beyond $-1.5 \mathrm{MPa}$ in the 
Table III. Morphological variables of glasshouse grown American chestnut seedlings after 36 days of exposure to well-watered and waterstressed conditions. Root to shoot ratio = root biomass divided by sum of leaf and stem biomass, leaf weight ratio $=$ leaf biomass divided by total biomass, leaf weight root ratio $=$ leaf biomass divided by root biomass, leaf area ratio $=$ leaf area divided by total biomass, leaf area root ratio $=$ leaf area divided by root biomass. Each variable is the mean of ten plants \pm standard error of the mean.

\begin{tabular}{lccc}
\hline Variables & Well-watered & Water-stressed & $p$-value* \\
\hline Total biomass $(\mathrm{g})$ & $7.93 \pm 2.09$ & $5.82 \pm 1.00$ & 0.013 \\
Root biomass $(\mathrm{g})$ & $2.59 \pm 0.62$ & $1.63 \pm 0.99$ & 0.001 \\
Leaf biomass $(\mathrm{g})$ & $3.76 \pm 0.94$ & $3.20 \pm 0.75$ & 0.153 \\
Stem biomass $(\mathrm{g})$ & $1.58 \pm 0.62$ & $0.99 \pm 0.22$ & 0.016 \\
Root to shoot ratio & $0.49 \pm 0.08$ & $0.40 \pm 0.09$ & 0.034 \\
Leaf weight ratio & $0.48 \pm 0.03$ & $0.55 \pm 0.06$ & 0.004 \\
Leaf weight root ratio & $1.47 \pm 0.22$ & $2.04 \pm 0.71$ & 0.035 \\
Leaf area $\left(\mathrm{cm}^{2}\right)$ & $603.0 \pm 124.3$ & $547.9 \pm 107.6$ & 0.304 \\
Specific leaf area $\left(\mathrm{cm}^{2} \mathrm{~g}^{-1}\right)$ & $161.6 \pm 11.8$ & $172.8 \pm 11.7$ & 0.047 \\
Leaf area ratio $\left(\mathrm{cm}^{2} \mathrm{~g}^{-1}\right)$ & $77.2 \pm 9.3$ & $94.2 \pm 9.4$ & 0.001 \\
Leaf area root ratio $\left(\mathrm{cm}^{2} \mathrm{~g}^{-1}\right)$ & $237.9 \pm 44.0$ & $348.6 \pm 108.9$ & 0.012 \\
\hline
\end{tabular}

* $p$-value was calculated based on separate variance $t$-test.

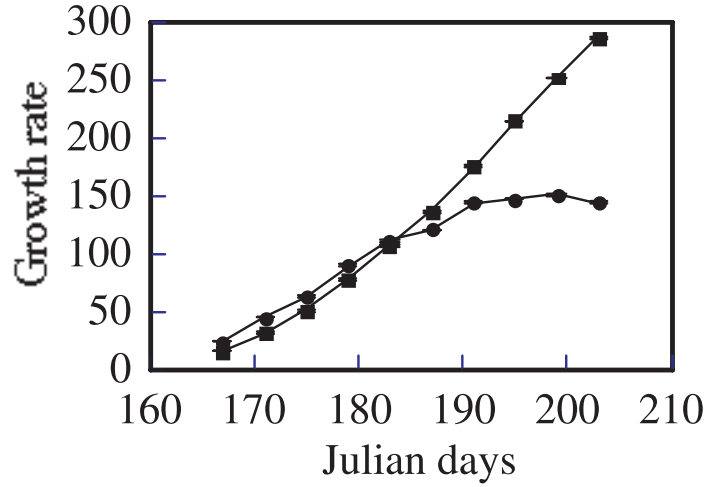

Figure 6. Absolute growth rate expressed as cylindrical volume index (the root collar diameter squared multiplied by height) measured at 10 4-day intervals for well-watered (ם) and water-stressed (•) American chestnut seedlings under glasshouse conditions. Each value is a mean $\pm \operatorname{SE}(n=10)$.

glasshouse population caused solar noon leaf wilt and symptoms of severe stress (leaf desiccation). After the majority of the growing season, the field site experienced substantial precipitation as a result of a hurricane. Consequently, the field experiment was terminated at a $\Psi_{\mathrm{p}}$ of $-1 \mathrm{MPa}$. Up until that time, however, the plastic sheeting prevented water recharge for approximately 3 continuous months of summer conditions. If not for the uncontrollable natural cause, it is probable that $g_{\mathrm{s}}$ of the field site seedlings would have continued to decrease to values that were similar to the glasshouse population because at a $\Psi_{\mathrm{p}}$ of approximately $-1 \mathrm{MPa}, A_{\text {net }}, g_{\mathrm{s}}$, and $\mathrm{WUE}_{\mathrm{i}}$ of the glasshouse and field populations began to converge. Nevertheless, we found that $\mathrm{WUE}_{\mathrm{i}}$ increased in both the glasshouse and field site in response to water stress. The lack of site difference in the overall $\mathrm{WUE}_{\mathrm{i}}$ response suggests that the drought response of American chestnut may be a species inherited trait.
In addition, Abrams et al. [2] found leaf water potential to be generally higher in American chestnut as compared to the deciduous hardwoods Quercus rubra L., Quercus prinus, and Quercus ilicifolia. The study by Abrams et al. [1], however, used sprouts from blight-killed trees, which meant that their root systems were likely larger than the co-occurring species to which they were compared.

Although water use efficiency is a parameter that does not always change in response to soil water content [25], our data support the hypothesis that water use efficiency of American chestnut seedlings increases in response to water stress regardless of the environment under which the seedlings were grown. This increase in water use efficiency, found in the gas exchange response to water stress, is attributed to the greater decrease in $g_{\mathrm{s}}$ as opposed to $A_{\text {net }}$ under glasshouse or field environmental conditions. Others (e.g., $[27,37])$ have reported a similar water use efficiency response in deciduous and conifer species. Although we were able to achieve more negative $\Psi_{\mathrm{p}}$ than the Abrams et al. [2] study, Table IV compares our $\mathrm{WUE}_{\mathrm{i}}$ values to those of other co-occurring species at similar $\Psi_{\mathrm{p}}$ values. Not only did our study find that American chestnut has a higher WUE $\mathrm{W}_{\mathrm{i}}$ than Quercus rubra L., Quercus prinus, and Quercus ilicifolia values calculated from Abrams et al. [2], but data from their study also confirms a higher $\mathrm{WUE}_{\mathrm{i}}$ for American chestnut. In a study that focused on drought adaptations of genotypes of Fraxinus pennsylvanica Marsh., Abrams et al. [1] reported gas exchange data that also was lower in $\mathrm{WUE}_{\mathrm{i}}$ for the species as compared to our American chestnut values. Bauerle et al. [5] found $\mathrm{WUE}_{\mathrm{i}}$ values in seedlings of Acer rubrum L. from both xeric and mesic sites that approached those of American chestnut, however, they were still not as high as the WUE $\mathrm{W}_{\mathrm{i}}$ values of American chestnut found in this study (Tab. IV).

Even though both experimental populations increased $W_{U}$, among the glasshouse and the field study we observed that drought did not significantly decrease leaf area and leaf 
Table IV. Comparison of instantaneous water use efficiency ( $\left.\mathrm{WUE}_{\mathrm{i}}\right)\left(\mathrm{g} \mathrm{CO}_{2}\left(\mathrm{~kg} \mathrm{H}_{2} \mathrm{O}^{-1}\right)\right)$ estimates of some deciduous species with overlapping geographic distribution. Predawn water potential $\left(\Psi_{\mathrm{p}}\right)(\mathrm{MPa})$ is reported for comparative purposes.

\begin{tabular}{lccc}
\hline Species & WUE $_{\mathrm{i}}$ & $\Psi_{\mathrm{p}}$ & Authors \\
\hline Acer rubrum (wet site) & 21.29 & -1.5 & Bauerle et al. 2003 \\
Acer rubrum (dry site) & 23.06 & -1.5 & Bauerle et al. 2003 \\
Castanea dentata (glasshouse) & 34.4 & -1.5 & This study \\
Castanea dentata (field) & 29.22 & -0.93 (max. $\left.\Psi_{\mathrm{p}}\right)$ & This study \\
Castanea dentata & 12.08 & -0.75 & Abrams et al. 1990 \\
Castanea dentata (glasshouse) & 20.05 & -0.75 & This study \\
Castanea dentata (field) & 20.97 & -0.75 & This study \\
Quercus ilicifolia & 11.58 & -0.68 & Abrams et al. 1990 \\
Quercus prinus & 11.91 & -0.78 & Abrams et al. 1990 \\
Quercus rubra & 11.51 & -0.94 & Abrams et al. 1990 \\
\hline
\end{tabular}

biomass in the glasshouse study. Two possible reasons for this observation are (1) most leaves were already formed and (2) expansion of preformed leaves is a priority of carbon allocation. As a result, less carbon is allocated to roots and stems. These allocation patterns may also explain why root to shoot ratio decreased with drought. In addition, field grown seedlings had significantly higher $A_{\text {net }}$ and $g_{\mathrm{s}}$ values when compared to glasshouse grown seedlings. One possible explanation for this observation could be the difference in environmental factors such as average VPD [7, 31]. Midday VPD values at the field site could have altered gas exchange ratios and thereby affected $\mathrm{WUE}_{\mathrm{i}}$ values [28]. Alternatively, the discrepancies could have been due to the higher PPFD of outdoor versus glasshouse conditions and thus, outdoor conditions may have provided more of a stimulus for stomatal opening. In addition, the age difference (30 days versus 2 year-old) and rooting depth (container versus field) could have contributed to the disparity. Warren et al. [39] points out that under severe water stress, damage to mesophyll is to be expected. In our study, $\mathrm{WUE}_{\mathrm{i}}$ values decreased abruptly beyond a $\Psi_{\mathrm{p}}$ of $-1.5 \mathrm{MPa}$ in the glasshouse population, following which the seedlings entered a period of severe water stress. Compared to well-watered conditions, drought stressed seedlings reduced the amount of light absorption in both populations. The decreased light absorption, however, only amounted to approximately $1-5 \%$ of absorbed PPFD and this amount may not be enough to substantially reduce radiation loads to preserve mesophyll integrity. We observed substantial leaf wilt and subsequent desiccation (severe water stress) after seedlings exceeded a $\Psi_{\mathrm{p}}$ of $-1.5 \mathrm{MPa}$ in the glasshouse population. Therefore, it is likely that the mesophyll became severely damaged due to inadequate evaporative cooling under midday high radiation load conditions. Alternatively, Costa E Silva et al. [10] attributed changes in the root biomass and hydraulic properties as possible methods to balance transpiration and water absorption, hence preserving carbon assimilation in Eucalyptus globulus clone CN5. This tolerance mechanism is, however, unlikely in our study because seedling root to shoot ratio did not increase with the drought treatment.
Our seedling growth response to water stress under either glasshouse or field conditions agrees with other studies that reported negative effects of water stress. Under well watered conditions, on the other hand, photosynthetic rates of field grown American chestnut seedlings were not as high as Acer rubrum L. [5] a common co-occurring species. Alternatively, field grown American chestnut photosynthetic rates were higher than other eastern USA deciduous species such as Acer saccharum, Quercus alba, Quercus stellata, and Juglans nigra values reported by Ni and Pallardy [29] and Quercus prinus, Quercus rubra, and Quercus ilicifolia reported by Abrams et al. [2]. The study by Ni and Pallardy, however, was conducted under glasshouse and growth chamber conditions, and their reported photosynthetic rates were comparable to our glasshouse gas exchange values. Our gas exchange results also support performance rank results found by Lathan [26], where he found that American chestnut seedlings ranked higher than Carya tomentosa, Quercus rubra, Fagus grandifolia, Nyssa sylvatica, and Liriodendron tulipifera across a broad range of resource combinations that affect competitive ability. In fact, after 6 and 7 years growth in southwest Wisconsin, Jacobs and Severeid [21] reported that American chestnut grew significantly faster than Juglans nigra L. and Quercus rubra L. Although the gap between relative species performance of seedlings and long-lived adults is large [26], the preblight dominance of American chestnut in eastern deciduous forests suggests that the resource competition hierarchy of American chestnut reported during the seedling stage will likely persist into adult stages too.

American chestnut's maintenance of photosynthesis under water stress conditions could be classified as a drought tolerance mechanism. When water deficit continues beyond the point where plants are able to escape without severe water potential decline, some plants are able to respond by engaging drought tolerance processes. For example, studies of $g_{\mathrm{s}}$ with respect to leaf water potential have generally indicated that stomatal closure coincides with reduction of bulk leaf (primarily mesophyll) water status. These processes permit cells to maintain turgor and withstand the damaging forces associated 
with more severe water loss. It may be that American chestnut possesses such inherent drought tolerant mechanisms. If so, heritability would be affected by the environment such that water stressed environments would accelerate successful reintroduction of blight-resistant American chestnut hybrids. Consequently, this aspect could significantly alter the current forest species composition. Alternatively, it is also possible that the combined effects of disturbance, climate, and land use history may prevent American chestnut from colonization as a canopy-dominant tree [32].

In conclusion, our study is the first to experimentally address American chestnut's ecophysiological response to water stress. Our findings indicate that American chestnut can maintain positive carbon gain under low substrate and soil water availability by increasing water use efficiency as drought progresses - a characteristic of drought tolerance. The simultaneous decreases in $g_{\mathrm{s}}$ and water potential maintained the balance between transpiration and photosynthesis when soil water availability declined, suggesting that American chestnut is adapted to tolerate water deficit. This trait, if maintained in the blight-resistant hybrids, could help survival and growth of planted seedlings when the species is reintroduced back to its formal native range.

Acknowledgements: The authors thank B.W. Bauerle for helpful discussions, L. Grimes for statistical advice, and E.M. Poulin for editorial comments. This work was partially funded by the Tree Fund, USDA Specialty Crops Program, and the South Carolina Experiment Station.

\section{REFERENCES}

[1] Abrams M.D., Kubiske M.E., Steiner K.C., Drought adaptations and responses in five genotypes of Fraxinus pennsylvanica Marsh.: photosynthesis, water relations and leaf morphology, Tree Physiol. 6 (1990) 305-315.

[2] Abrams M.D., Schultz J.C., Kleiner K.W., Ecophysiological responses in mesic versus xeric hardwood species to an early-season drought in central Pennsylvania, For. Sci. 36 (1990) 970-981.

[3] Bauerle W.L., Hinckley T.M., Čermák J., Kučera J., Bible K., The canopy water relations of old-growth Douglas-fir trees, Trees 13 (1999) 211-217.

[4] Bauerle W.L., Inman W.W., Dudley J.B., Leaf abscisic acid accumulation in response to substrate water content: Linking leaf gas exchange regulation with leaf abscisic acid concentration, J. Am. Soc. Hortic. Sci. 131 (2006) 295-301.

[5] Bauerle W.L., Whitlow T.H., Setter T.L., Bauerle T.L., Vermeylen F.M., Ecophysiology of Acer rubrum L. seedlings from contrasting hydrologic habitats: growth, gas exchange, tissue water relations, abscisic acid, and carbon isotope discrimination, Tree Physiol. 23 (2003) 841-850.

[6] Bauerle W.L., Weston D.J., Bowden J.D., Dudley J.B., Toler J.E. Leaf absorptance of photosynthetically active radiation in relation to chlorophyll meter estimates among woody plant species, Sci. Hortic. 101 (2004) 169-178.

[7] Bauerle W.L., Whitlow T.H., Setter T.L., Vermeylen F.M., Abscisic acid synthesis in Acer rubrum L. leaves - A vapor-pressure-deficitmediated response, J. Am. Soc. Hortic. Sci. 129 (2004) 182-187.

[8] Brooks A.B., Castanea dentata, Castanea 51 (1937) 239-244.
[9] Buttrick P.L., Holmes J.S., Preliminary report on the chestnut in North Carolina made in connection with a cooperative investigation if the chestnut bark disease, North Carolina Geological and Economic Survey, Raleigh, NC, 1913

[10] Costa E Silva F., Shvaleva A., Maroco J.P., Almeida M.H., Chaves M.M., Pereira J.S., Response to water stress in two Eucalyptus globulus clones differing in drought tolerance, Tree Physiol. 24 (2004) $1165-1172$.

[11] Farquhar G., von Caemmerer S., Modelling of photosynthetic response to environmental conditions, in: Encyclopedia of Plant Physiology, II, Lange O.L., Nobel P.S., Osmond C.B., Ziegler H., (Eds.), Physiological Plant Ecology, Springer-Verlag, Berlin (1982) 549-588.

[12] Farquhar G.D., von Caemmerer S., Berry J.A., A biochemical model of photosynthetic $\mathrm{CO}_{2}$ assimilation in leaves of $\mathrm{C}_{3}$ species, Planta 149 (1980) 78-90.

[13] Fulton A., Bucher R., Olson B., Schwankl L., Gilles C., Bertagna N., Walton J., Shackel K., Rapid equilibration of leaf and stem water potential under field conditions in almonds, walnuts, and prunes, HortTechnology 11 (2001) 609-615.

[14] Gregory J.M., Mitchell J.F.B., Brady A.J., Summer drought in northern midlatitudes in a time-dependent $\mathrm{CO}_{2}$ climate experiment, J. Clim. 10 (1997) 662-686.

[15] Griffin G.J., Clay Smith H., Dietz A., Elkins J.R., Importance if hardwood competition to American chestnut survival, growth, and blight development in forest clearcuts, Can. J. Bot. 69 (1991) 1804 1809 .

[16] Griffin G.J., American chestnut survival in under story mesic sites following the chestnut blight pandemic, Can. J. Bot. 70 (1992) $1950-1956$.

[17] Harley P.C., Sharkey T.D., An improved model of $C_{3}$ photosynthesis at high $\mathrm{CO}_{2}$ : Reversed $\mathrm{O}_{2}$ sensitivity explained by lack of glycerate re-entry into the chloroplast, Photosynth. Res. 27 (1991) 169-178.

[18] Harley P.C., Thomas R.B., Reynolds J.F., Strain B.R., Modelling photosynthesis of cotton grown in elevated $\mathrm{CO}_{2}$, Plant Cell Environ. 15 (1992) 271-282.

[19] Hoerling M., Kumar A., The perfect ocean for drought, Science 299 (2003) 691-694.

[20] Huang H., Dane F., Kubisiak T., Allozyme and RAPD analysis of the genetic diversity and geographic variation in wild populations of the American chestnut (Fagaceae), Amer. J. Bot. 85 (1998) 10131021.

[21] Jacobs D.F., Severeid L.R., Dominance of interplanted American chestnut (Castanea dentata) in southwestern Wisconsin, USA, For. Ecol. Manage. 191 (2003) 111-120.

[22] Keever C., Present composition of some stands of the former oakchestnut forest in the southern Blue Ridge Mountains, Ecology 34 (1953) 44-55.

[23] Kirschbaum M.U.F., Farquhar G.D., Temperature dependence of whole-leaf photosynthesis in Eucalyptus pauciflora Sieb. ex Spreng, Aust. J. Plant Physiol. 11 (1984) 519-538.

[24] Kozlowski T.T., Pallardy S.G., Physiology of Woody Plants, 2nd ed., Academic Press, San Diego, 1997, pp. 411.

[25] Kramer P.J., Boyer J.S., Water relations of plants, Academic Press, New York, 1995, $495 \mathrm{p}$.

[26] Latham R.E., Co-occurring tree species change rank in seedling performance with resources varied experimentally, Ecology 73 (1992) 2129-2144.

[27] Nagakura J., Shigenaga H., Akama A., Takahashi M., Growth and transpiration of Japanese cedar (Cryptomeria japonica) and Hinoki cypress (Chamaecyparis obtusa) seedlings in response to soil water content, Tree Physiol. 24 (2004) 1203-1208.

[28] Ngugi M.R., Hunt M.A., Doley D., Ryan P., Dart P.J., Effects of soil water availability on water use efficiency of Eucalyptus cloeziana and Eucalyptus argophloia plants, Aust. J. Bot. 51 (2003) 159-166. 
[29] Ni B.-R., Pallardy S.G., Response of gas exchange to water stress in seedlings of woody angiosperms, Tree Physiol. 8 (1991) 1-9.

[30] Olsson T., Leverenz J.W., Non-uniform stomatal closure and the apparent convexity of the photosynthetic photon flux density response curve, Plant Cell Environ. 17 (1994) 701-710.

[31] Oren R., Sperry J.S., Katul G.G., Pataki D.E., Ewers B.E., Phillips N., Schäfer K.V.R., Survey and synthesis of intra- and interspecific variation in stomatal sensitivity to vapour pressure deficit, Plant Cell Environ. 22 (1999) 1515-1526.

[32] Paillet F.L., Chestnut: history and ecology of a transformed species, J. Biogeogr. 29 (2002) 1517-1530.

[33] Parsons R., Weyers J.D.B., Lawson T., Godber I.M., Rapid and straightforward estimates of photosynthetic characteristics using a portable gas exchange system, Photosynthetica, 34 (1997) 265-279.

[34] Reed F.W., Examination of a forest tract in western North Carolina, USDA For. Serv. Bull. 60 (1905) 29 p.

[35] Shackel K., Fulton A., Buchner R., Olsen B., Schwankl L., Gilles C., Bertagna N., Walton J., Rapid equilibration of leaf and stem water potential under field conditions, HortSci. 36 (2001) 430.
[36] Sharkey T.D., Photosynthesis of intact leaves of $\mathrm{C}_{3}$ plants: physics, physiology and rate limitations, Bot. Rev. 51 (1985) 53-105.

[37] Smit J., van den Driessche R., Root growth and water use efficiency of Douglas-fir (Pseudotsuga menziensii (Mirb.) Franco) and lodgepole pine (Pinus contorta Dougl.) seedlings, Tree Physiol. 11 (1992) 401-410.

[38] Walther G.-R., Post E., Convey P., Menzel A., Parmesan C., Beebee T.J.C., Fromentin J.-C., Hoegh-Guldberg O., Beirlein F., Ecological responses to recent climate change, Nature 416 (2002) 389-395.

[39] Warren C.R., Livingston N.J., Turpin D.H., Water stress decreases the transfer conductance of Douglas-fir (Pseudotsuga menziesii) seedlings, Tree Physiol. 24 (2004) 971-979.

[40] Wullschleger S.D., Biochemical limitations to carbon assimilation in $C_{3}$ plants - A retrospective analysis of the $A / C_{i}$ curves from 109 species, J. Exp. Bot. 44 (1993) 907-920.

[41] Zon R., Chestnut in Southern Maryland, US Department of Agriculture, Bureau of Forestry, USA, Bull. No. 53, 1904. 